\title{
Reform in College English Teaching Based on PETOE of Engineering Institute
}

\author{
Si-Yang LIU \\ Foreign Language Department, JLICT \\ Jilin City, China \\ liu990205@163.com
}

\begin{abstract}
Based on the surveys on the current situation of college English teaching in engineering undergraduate institutes in China, this paper tries to explore the reform roads of PETOEbased college English teaching. The suggestions are given from five aspects of adjusting teaching objectives, reconstructing a curriculum system, adopting effective teaching models, establishing a multidimensional teaching evaluation system and strengthening the construction of college English teaching staff. The reform will contribute to the improvement of college English teaching quality, the smooth implementation of PETOE and the achievement of the goal of training outstanding engineering talents. The study is a try to practice PETOE issued by the Ministry of Education, which regards developing the international engineering talents as one of its strategic priorities. It will establish a connection between English teaching and the higher engineering education in China, aiming to change the situation that the international competitiveness of the graduates is not strong with the English as the obstacle.
\end{abstract}

Keywords-PETOE (A plan for educating and training outstanding engineers); College English; Teaching reform; Engineering institute

\section{INTRODUCTION}

In China the higher engineering education is widely implemented in more than a thousand colleges and universities, accounting for $90 \%$ of the total number. So China is worthy of the name of engineering education power. However, the international competitiveness of our graduates in engineering education is not strong. In 2010, the Ministry of Education started "A Plan for Educating and Training Outstanding Engineers" (hereinafter referred to as "PETOE"), which is the important education reform project to implement ideas in "The National Outline for Medium and Long Term Education Reform and Development (2010-2020)" and “The National Program for Medium and Long Term Talent Development (2010-2020)”. PETOE aims to cultivate a large number of high-quality engineering and technical talents with innovative ability to adapt to economic and social development needs, to serve the fulfillment of building a new industrialized and innovative country, and a talents state. Therefore, PETOE plays a vital role to guide universities to train talents responding to the social demand and enhance the quality of higher engineering education comprehensively. ${ }^{[1]}$ Under this background, in order to better implement PETOE, it is of important and practical significance for engineering institutes to explore an ideal model of training outstanding engineers in college English teaching reform, with the following four aspects being the majors concerns.

\section{CURRENT Situation OF COLLEGE ENGLiSH TEACHING IN ENGINEERING INSTITUTES}

Qiao Xiaoliu has conducted surveys on the current situation of college English teaching in engineering undergraduate institutes in China. ${ }^{[2]}$ The surveys of undergraduates and graduates from more than 20 engineering institutes focused on four aspects of learning objectives, language skills, convergence of public English and professional English learning, and humanistic atmosphere of teaching. In the aspect of English Learning Objectives, including internal goals and external goals, ${ }^{[3]}$ the survey showed that engineering students paid more attention to such internal goals as developing knowledge and cross-cultural cognition, and such external goals as employment and professional development. In particular, $90 \%$ of graduates thought that the goal of English learning should be professional development. In terms of language skills, the survey found that students ranked the order of importance of basic skills as follows: listening, speaking, reading, translating, writing; while reading ranked first in their actual mastery of the above skills, followed by listening, translation, speaking and writing. The investigators also found an interesting phenomenon: Although listening and speaking were considered as important by students, they didn't have perfect mastery of these two skills, to which the classroom teaching time allocated was highly inconsistent with their dependence on teachers. A survey on the linkages between college English and professional English teaching in undergraduate engineering institutes claimed that the vast majority of college English teaching content did not involve students' major at all. Up to $92 \%$ of students thought that college English was of no help or little help for their professional English learning. 85\% of the respondents were dissatisfied with the professional English teaching. The result of the survey on the humanities atmosphere revealed that there were no liberal arts in 7 of the 10 engineering colleges and universities and almost all engineering majors did not offer college Chinese courses. Only $16 \%$ of the respondents thought they were good at Chinese. Based on the findings of the surveys, it must be admitted that there is a serious lack in the atmosphere of humanities in China's engineering colleges and universities. College English teaching reform is a must. 


\section{THE IDEAS OF COLLEGE ENGLISH TEACHING REFORM BASED ON PETOE}

Engineering colleges and universities, especially local engineering institutes can take targeted measures to explore PETOE-based college English teaching reform roads which suit the institutes' own characteristics.

\section{A. Setting Multiple College English Teaching Objectives}

In 2007 the Ministry of Education issued "College English Curriculum Requirements”(hereinafter referred to as "Curriculum Requirements"), pointing out that "The objective of College English is to develop students' ability to use English in a well-rounded way, especially in listening and speaking skills, so that in their future studies and careers as well as social interactions they will be able to communicate effectively, and at the same time enhance their ability to study independently and improve their general cultural awareness so as to meet the needs of China's social development and international exchanges." ${ }^{[4]}$ The requirements, to some extent, agree with some standards of engineer training at undergraduate level. The current international engineering education has four common trends: emphasizing the engineers' strong sense of social responsibility; strengthening the engineers' comprehensive quality; implementing leadership training program; training engineers' international vision and cross-cultural communication ability. Seen From the "The General Standards for PETOE" issued by the Ministry of Education, PETOE emphasizes to enhance the overall quality of the talents training, in which the humanities accomplishment is an important part. ${ }^{[5]}$ Robert Galisson, the founder of the foreign language and culture teaching in law, put forward the proposition that the foreign language teaching starts from training the students' language skills, then develops to cultivating students' skills of language and culture, and will ultimately educate people through language and culture. Now the humanities courses such as Chinese have been compressed in many engineering institutes, and consequently there is serious shortage of humanistic atmosphere on campus. College English must take the responsibility to change this situation. On the basis of understanding national needs and foreign language learning rules, taking into consideration the "Curriculum Requirements" and the type of the institute with its special requirements of a foreign language, college English teaching of the engineering institute should combine the teaching objective and the type of the school closely, making college English teaching an integral part of higher education of the students. ${ }^{[6]}$ For this purpose, the objective of the college English teaching under the background of PETOE should be composed of multiple secondary targets. The ultimate goal is, according to the outstanding engineer training specifications, to improve students' English comprehensive application competence with the global vision, to shape students' personality and enhance their employment competitiveness and development potential to be engaged in the engineering occupation.

\section{B. Constructing a College English Modular Curriculum System}

Curriculum is the basic part of teaching, whether the curriculum design is scientific or not is directly related to the quality of teaching. In a college English teaching system for PETOE, two parts of modules, i. e., the general education module and the professional education module should be constructed, which is the overall consideration of a undergraduate English teaching system. This system can not only consolidate the public English teaching, but also deepen the English teaching related to specific professional engineering education, thus the connection between the public English teaching and the professional English teaching can be established in the system, with the latter being the extension and expansion of the former. General education module is mainly composed of public English and English elective courses, and professional education module consists of ESP courses. Students can complete the public English learning in the first two years, and then dedicate to the academic English and professional English learning in the third and fourth years. At the same time, students can employ themselves in the study of elective courses from the third to the seventh semester. The modular teaching system ensures students to receive English education in four continuous years, highlights the cultivation of students' comprehensive English application ability, embodying the principle of study meeting the needs of students' life and serving the practical purpose of engineering career. As for the general education module, the curriculum here must comply with certain norms, i. e., taking "Curriculum Requirements" as the framework. In addition to the comprehensive public English courses that take reading, writing, translation, speaking and audiovisual as the main content, many optional courses should be offered. These courses can include such ones about language knowledge as English Grammar, English Vocabulary, such ones about language and culture as British and American Society and Culture, the Appreciation of British and American Literature, English Film Appreciation and Comparison between Chinese and Western Cultures, or those about language skills such as English Speech, English Practical Writing, etc., aiming to train the quality of the world citizen with multi-cultural vision. In the professional English education module, the curriculum must be flexible, which should particularly highlight the characteristics of the professional disciplines of the institute. And meanwhile in teaching, some English learning materials suitable for the students' cognitive level and closely related to their specialties should be selectively added, so as to cultivate the professional quality of global applied engineering talents.

\section{Adopting Individualized College English Teaching Model}

PETOE emphasizes to cultivate students' learning ability, i. e., the ability of information acquisition and career development. "Curriculum Requirements" define that "the college English teaching model should be built on the modern information technology, particularly network technology, so that English language teaching and learning will be, to a certain extent, free from the constriction of time or place and geared towards students' individualized and autonomous learning." ${ }^{[7]}$ 
"The National Outline for Medium and Long Term Education Reform and Development (2010-2020)” points out that education should take the student as the main body, take the teacher as the leadership, and give full play to the initiative of students. The starting point and foothold of school work is to promote the healthy growth of students. ${ }^{[8]}$ At present, the domestic colleges and universities have generally established college English network teaching platform, the idea of "student-centered and teacher-leading" should be used as the guiding ideology and the core principle of the teaching model in college English teaching based on PETOE, so as to realize the effective combination of the network and classroom teaching, the combination of classroom teaching and extracurricular practice which will extend college English teaching. Schools can provide college English teaching resources, the college English audio-visual learning system and the network teaching platform for students to carry out autonomous English learning based on their own foundation. In addition, a variety of English second classroom activities can be held. Such activities as English speech contests, the English writing contests, English songs competitions and English drama contests, etc. will attract the students of different levels to participate and stimulate their interest in learning English. As a result, their English can be improved in different degrees through participating in the second classroom activities.

Item eleven of "The General Standards for PETOE" requires engineering talents to have a certain international perspective and the preliminary competence of communication, competition and cooperation in the cross-cultural environment. ${ }^{[9]}$ Combined with this requirement and the educational philosophy of application-oriented undergraduate colleges, the selective courses of language and culture and ESP courses can adopt a content-based instruction model. Contentbased instruction is using a certain subject as the basic content in language teaching and then to realize the combination of language and knowledge. The purpose of content-based instruction is to promote the language improvement on the basis of the enhancement of the students' discipline knowledge and cognitive ability. The distinctive features of content-based instruction are as follows: taking subject knowledge as the core, using authentic language, learning new information and designing the courses based on the needs of students with different starting points. In the process of content-based instruction, when the teachers select corpus and design tasks, it is necessary for them to take into full consideration the students' language level, cognitive, emotional needs, future occupation demands and personal interests. The corpus selected should be real and meaningful, and the students should be required to use the target language to complete the real-life tasks. In terms of the students, the content-based teaching of ESP will not only inspire their enthusiasm to learn English, but also improve their ability of critical thinking and communication, pave the way for their future career in the global market.

\section{Establishing a Multidimensional Teaching Evaluation System}

A comprehensive, objective, scientific and accurate evaluation system is of vital importance to the achievement of the course goals. PETOE-based college English teaching evaluation should consists of three dimensions of evaluating students' learning, evaluating teachers' teaching and evaluating the effects of curriculum and these three dimensions will influence and promote each other. As for the assessment of students' learning effects, "Curriculum Requirements” propose the notion of combining formative assessment with summative assessment. In the application-oriented universities, these two kinds of assessment should be attached equal importance to, in accordance with the students' characteristics. Formative assessment includes classroom performance, assignments, quizzes, oral performance, midterm exam results; summative assessment mainly consists of final tests, proficiency tests and some national tests. In order to make the usual assessment more reasonable and promote students' effective learning, students' autonomous learning should be brought into formative assessment. Generally, teachers give students specific tasks and provide some network resources for students' autonomous learning, then the record of students' outside of classroom activities and online self-learning data, the files of students' study result will be kept in formative assessment by means of such various methods as tests, assignments and the forum, etc. at the network teaching platform. Besides, students should conduct self-assessment in every semester so as to adjust their learning attitude and learning strategies. As for the assessment of teachers' teaching process and effects, it is suggested to adopt the approach of combing students' assessment of teaching, teachers' self-assessment and peer assessment, which helps teachers understand the teaching effect from multiple angles, obtain feedback and adjust teaching strategies in time. The evaluation of the effects of curriculum conducted by students, teachers and experts will contribute to the timely adjustment of the course content and the teaching model, to the optimization of the course setting and the enhancement of teaching effects.

\section{E. Strengthening the Construction of College English Teaching Staff}

Strengthening the construction of college English teaching staff and improving the comprehensive quality of teachers are the keys to ensure the success of English teaching reform based on PETOE. However, compared with teachers of science and engineering specialties, many problems exist in the structure of college English teaching staff. College English teachers, with a high proportion of young females and a heavy workload, usually do not have high professional titles and doctorates, which results in poor team stability and a prominent contradiction between work and study, teaching and scientific research. Besides, great changes have taken place in college English teaching environment and teaching requirements. Therefore, it is obviously a challenge for local engineering institutes to strengthen the construction of college English teaching staff in the pilot class of PETOE. First of all, teachers should change their teaching ideas and re-position their roles. It is necessary for the college English teachers to master advanced international educational concepts and undertake 
more diversified and multi-functional roles and tasks. By transforming into the organizers, participants and evaluation subjects of the teaching activities from the traditional teaching subjects and teaching masters, they can design and manage teaching activities more scientifically and effectively. Secondly, teachers should improve their professional level and have a wide range of knowledge. In order to develop first-class and excellent engineers, the college English teachers are required to widen their visions and broaden their horizons. They should master network knowledge and subject frontier knowledge, understand extensive general knowledge, especially related professional knowledge of the pilot program. Thirdly, an English teaching team of PETOE pilot classes should be set up. The team members must be a group of teachers with higher academic qualifications, relatively rich teaching experience, high professional quality and strong scientific research ability. Through training, the team members will learn and understand relevant documents of the state and school on PETOE. They will personally draw up the English teaching syllabus of the pilot program and actively participate in the discussion and formulation of training plans of various departments. English teachers are also required to carry out targeted teaching and research work in accordance with the training program of the PETOE pilot classes. In PETOE pilot program teaching, it is necessary to form a harmonious teaching atmosphere in which English teachers and other teachers should regularly carry on discussions, collective lesson preparation, teaching and research activities and so on. In this process, cooperation and communication can be strengthened, complementarities of knowledge, teaching and research can be realized, which will ultimately enhance teachers' comprehensive quality and improve the quality of college English teaching.

\section{CONCLUSION}

PETOE is an important measure for our country to move towards the engineering education powerful nation. Its core is to cultivate engineering and technical talents of high quality with global consciousness and competition ability. In this talents-training process, foreign language education, especially college English teaching is an indispensable part. Facing the important opportunities and challenges of PETOE, college English teaching in engineering institutes must conform to the connotation of the requirements. PETOE-based college English teaching should set a clear objective, reconstruct a curriculum system, adopt effective teaching models, and establish a multidimensional teaching evaluation system to adjust teaching strategies, so that PETOE can be implemented smoothly and the goal of cultivating outstanding engineering talents can be achieved.

\section{ACKNOWLEDGMENT}

The study is supported by The Research Center for Foreign Language Education in Engineering Institutes of Jilin Province, The Key Research Base of Humanities and Social Science of Jilin Province.

\section{REFERENCES}

[1] Lin Jian, "On the university working program of A Plan for Educating and Training Outstanding Engineers", J. Research in Higher Education of Engineering. 4 (2010) 21-29. (In Chinese)

[2] Qiao Xiaoliu, "Reform in college English in the light of PETOE", J. Shandong Foreign Language Teaching Journal. China, vol. 148, pp. 6974. (In Chinese)

[3] Cook, V. The goal of ELF: "Reproducing native speakers or promoting multi-competence among second language users?”, International Handbook of Language Teaching, 2007(Springer) : 237-248.

[4] Ministry of Education of the People's Republic of China. College English curriculum requirements, M. Beijing: Higher Education Press, 2007. (In Chinese)

[5] Ministry of Education of the People's Republic of China. The General Standards for a Plan for Educating and Training Outstanding Engineers, 2013. (In Chinese)

[6] Su Dingfang, "College English classroom teaching, what we teach, how to teach?”, J. Foreign Language World. China, vol. 141, pp. 26-32. (In Chinese)

[7] Ministry of Education of the People's Republic of China. College English curriculum requirements, M. Beijing: Higher Education Press, 2007. (In Chinese)

[8] Ministry of Education of the People's Republic of China. The National Outline for Medium and Long Term Education Reform and Development (2010-2020), 2010. (In Chinese)

[9] Ministry of Education of the People's Republic of China. The General Standards for a Plan for Educating and Training Outstanding Engineers, 2013. (In Chinese) 